\title{
Faktor-Faktor yang Mempengaruhi Tingkat Populasi Ternak Kerbau di Kecamatan Biboki Anleu Kabupaten Timor Tengah Utara
}

Arnoldus Ikun ${ }^{\mathrm{a}}$

${ }^{a}$ Fakultas Pertanian, Universitas Timor, Kefamenanu, TTU - NTT, Indonesia.

\section{Article Info}

\section{Article history:}

Received 18 Mei 2018

Received in revised form 15 Juni 2018

Accepted 3 Juli 2018

DOI:

https://doi.org/10.32938/ja.v3i3.537

Keywords:

Calving Rate

Karakteristik Peternak

Mortalitas

Natural Increase

Populasi Kerbau

\section{Abstrak}

Penelitian ini bertujuan untuk menganalisis faktor-faktor yang mempengaruhi tingkat populasi ternak kerbau di Kecamatan Biboki Anleu. Penelitian menggunakan metode survei dengan teknik pengambilan sampel secara purpose sampling yang melibatkan seluruh peternak di wilayah setempat. Variabel penelitian meliputi karakteristik peternak, populasi ternak, calving rate, mortalitas, tingkat penjualan, natural increase, dan tata laksana pemeliharaan ternak kerbau di Kecamatan Biboki Anleu. Hasil penelitian menunjukkan bahwa tingkat pendidikan peternak didominasi oleh Sekolah Dasar/Sekolah Rakyat (SR) sebanyak 22 orang $(56,4 \%)$, dengan berprofesi sebagai petani peternak sebanyak 38 orang $(97,4 \%)$. Umur peternak sebagian besar berkisar 45-68 tahun sebanyak 22 orang (56,4\%) dengan pengalaman beternak 21 tahun. Jumlah pemilihan ternak didominasi oleh peternak yang memelihara kerbau sebesar 1-5 ekor sebanyak 21 orang $(50,8 \%)$. Tingkat populasi kerbau rata-rata sebesar $281 \pm 6,39$ dengan rata-rata calving rate dan mortalitas masing-masing sebesar $85+2,43$ ekor $(57,55 \%)$ dan $19,8 \pm 1,11$. Selain itu, tingkat penjualan pada ternak muda sebesar $25 \pm 1,17$, dan ternak dewasa sebesar $28 \pm 1,59$. Perkembangan ternak kerbau di Kecamatan Biboki Anleu positif dengan persentase angka Natural Increase (NI) sebesar 19,2\%, dengan Location Quationts (LQ) sebesar 5,77. Ketersediaan pejantan untuk mengawini induk cukup memadai sebesar 32,25 $\pm 5,65$ dengan rasio pejantan: betina 1:5. Secara umum motivasi peternak memelihara ternak adalah untuk memenuhi biaya pendidikan anak, kebutuhan keluarga, sosial budaya (adat) dan pengadaan perlengkapan pertanian. Dapat disimpulkan bahwa usaha pemeliharaan ternak kerbau di Kecamatan Biboki Anleu sangat potensial karena didukung oleh wilayah yang cukup luas dengan persentase angka Natural Increase (NI), Calving Rate (CR) dan Location Quationts (LQ) yang cukup tinggi, serta rasio jantan : betina yang memadai.

\section{Pendahuluan}

Peningkatan populasi ternak merupakan salah satu program pemerintah dalam rangka penyediaan persediaan ternak untuk mencukupi kebutuhan pangan dalam bentuk daging. Kerbau merupakan ternak ruminansia yang dipelihara dengan tujuan sebagai penghasil daging selain itu dapat dimanfaatkan membantu dalam mengolah lahan. Ternak kerbau adalah ternak lokal yang hidup pada panas dan lembab, khusus di daerah belahan utara tropika (Deptan, 2008). Peran ternak ini di desa dapat membantu petani peternak dalam membajak sawah, keperluan adat dan sebagai penunjang perekonomian para peternak sendiri, namun saat ini usaha dibidang peternakan kerbau belum memperoleh penanganan secara intensif dan masih perlu didorong serta dikembangkan. Usaha peternakan kerbau merupakan usaha sambilan untuk menambah pendapatan bagi peternak yan memeliharanya serta sebagai sumber ekonomi yang sangat berarti bagi petan peternak pedesaan. Selain mudah untuk dipelihara ternak kerbau juga sanggup untuk memanfaatkan rumput yang berkualitas rendah, toleran terhadap parasit dan keberadaannya telah menyatu sedemikian rupa dengan beragam kehidupan sosial dan budaya petani. Kerbau mempunyai keistimewaan tersendiri dibanding sapi. Menurut Hellyward dkk., (2000), kemampuan ternak kerbau ini terlihat dalam hal memanfaatkan serat kasar, daya adaptasi yang tinggi terhadap daerah yang berkondisi yang kurang menguntungkan, serta berat badannya yang relatif besar, sehingga sangat besar kemungkinan untuk dikembangkan sebagai ternak penghasil daging yang baik.

Hasinah (2006), mengatakan bahwa pengembangan populasi ternak kerbau dapat diarahkan pada wilayah-wilayah yang masih memiliki potens pemeliharaan yang besar seperti luasnya padang penggembalaan. Provinsi Nusa Tenggara Timur (NTT) merupakan salah satu wilayah yang berpotensi sebaga pengembangan populasi ternak kerbau. Menurut data Statistik NTT 2017 populasi ternak kerbau sebanyak 141.075 ekor, berdasarkan tingkat populasi ternak kerbau di Indonesia, NTT menempati urutan ke tiga setelah Sulawes Tenggara dan Nusa Tenggara Barat (BPS NTT 2017), pernah dijuluki sebagai gudang ternak yang didukung dengan keadaan iklim dan adaptasi ternak kerbau yang hidup di daerah panas dan lembab. Jika dilihat dari harga ternak kerbau lebih mahal dibandingkan ternak sapi, sehingga perlu adanya upaya pelestarian plasma nutfah ternak kerbau. Menurut Priyanti \& Saptati (2007), pengembangan ternak kerbau dapat dipergunakan sebagai pemicu pengembangan kegiatan budidaya untuk menghasilkan bakalan (cow calf operation) sekaligus sebaga upaya pelestarian plasma nutfah ternak kerbau, peluang ini akan semakin bertambah dengan besarnya potensi sumber daya alam dan sumber daya manusia yang dapat diarahkan untuk pengembangan ternak kerbau di Indonesia

Usaha budidaya ternak kerbau yang dilaksanakan oleh masyarakat $\mathrm{d}$ Kabupaten Timor Tengah Utara (TTU) mengalami pasang surut seiring dengan permasalahan yang dihadapi oleh masyarakat terkait pengembangan ternak kerbau. Penyebab pasang surut populasi ternak kerbau di Kabupaten TTU antara lain, keterbatasan sumber daya manusia, keterbatasan pakan ternak pada musim paceklik, lahan penggembalaan yang terbatas dipengaruhi oleh penambahan pemukiman, pembukaan lahan baru, lamanya tingkat kebuntingan, panjangnya jarak bergudel, kurangnya pejantan, tingginya tingkat mortalitas. Selain itu, tingkat pendapatan masyarakat rendah menyebabkan ternak kerbau yang masih produktif dijual untuk memenuhi kebutuhan hidup sehari-hari serta programprogram pemerintah kabupaten TTU yang tidak mendukung pengembangan ternak kerbau dan hanya berorientasi pada usaha pengembangan ternak sapi. Ha ini dapat dilihat pada data Statistik yang memperlihatkan populasi ternak kerbau dari 5 tahun terakhir masing-masing pada tahun 2013 sebanyak 558 ekor, 2014 sebanyak 720 ekor, 2015 sebanyak 720 ekor, dan 2016 sebanyak 681 ekor (BPS TTU, 2017)

\section{Metode}

Penelitian ini dilaksanakan di Lima (5) desa di Kecamatan Biboki Anleu yaitu Desa Oemanu, Desa Ponu, Desa Nifutasi, Desa Kotafoun, Desa Tuamese, Desa Nonotbatan, Kabupaten TTU. Waktu penelitian berlangsung selama 1 bulan dimulai pada 1 Maret sampai 10 April 2018. Penelitian ini menggunakan metode deskriptif untuk menjelaskan dan menggambarkan pola pemeliharaan ternak kerbau dan faktor-faktor yang mempengaruhi populasi ternak kerbau. Langkah-langkah yang digunakan dalam penelitian ini adalah sebagai berikut observasi awal dengan mendatangi lokasi penelitian dan mengambil data awal sebagai dasar melakukan penelitian ini. Data awal yang amati berupa data sekunder yang ambil dari dinas Peternakan Kabupaten TTU dan pengamatan langsung di lapangan, Populasi dalam penelitian ini diambil secara purpose sampling (pengambilan data secara sengaja) pada peternak yang memiliki ternak kerbau sesuai dengan sebaran populasi ternak kerbau di Kecamatan Biboki Anleu.

Populasi ternak Kerbau yang meliputi banyaknya jumlah gudel kerbau (gudel), kerbau muda, dan kerbau dewasa yang diperoleh dari lokasi penelitian oleh peneliti, melalui wawancara dan menghitung langsung di lapangan. Jumlah gudel yang lahir per tahun dibagi dengan jumlah populasi pada struktur populasi dikali $100 \%$, melalui wawancara dan menghitung langsung di lapangan dan menggunakan rumus Dania $d k k$., (2013)

\section{Kelahiran(\%) : $\frac{\text { jumlah gudel yang lahir pertahun }}{\text { jumlah induk dalam populasi pertahun }} 100 \%$}

Banyaknya ternak yang mati dihitung dalam persentase pada suatu periode tertentu, dipisahkan antara kematian gudel, ternak muda dan ternak dewasa (Dania $d k k ., 2013)$.

Kematian(\%)(0- 6 bulan) : $\frac{\text { jumlah gudel yang mati pertahun }}{\text { jumlah gudel yang lahir pertahun }} 100 \%$

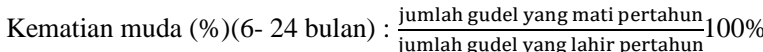

$\begin{array}{lccc}\text { Kematian dewasa } & (\%)(> & 24 & \text { bulan }) \\ \text { jumlah dewasa yang mati pertahun } & & \end{array}$

jumlah populasi dewasa pertahun $100 \%$

Pertumbuhan alami/natural increase (NI) diperoleh dengan cara menghitung Selisih antara angka kelahiran dengan angka kematian dinyatakan dalam persen (Dania $d k k ., 2013$ ).

Analisa data menggunakan analisis deskriptif dengan cara menghitung persentase, rata-rata, standar deviasi keragaman populasi, jenis kelamin dan umur ternak kerbau, Sugiyono, 2007.

\section{Hasil dan Pembahasan}

\subsection{Gambaran Umum Lokasi Penelitian}

Kecamatan Biboki Anleu merupakan salah satu kecamatan dari 24 kecamatan yang berada dalam sistem pemerintahan Kabupaten Timor Tengah Utara (TTU) Provinsi Nusa Tenggara Timur (NTT), dengan letak astronomis Kecamatan Biboki Anleu antara 124037'20'E - 124'52'40'E dan 9013'40'S 9032'0”'S. Kecamatan ini memiliki 9 desa yaitu Desa Oemanu, Desa Nifutasi, Desa Ponu, Desa Kotafoun, Desa Tuamese, Desa Maukabatan, Desa Sifaniha, Desa Nonotbatan, dan Desa Motadik. Secara umum luas Kecamatan Biboki Anleu adalah 206,40 $\mathrm{km}^{2}$ atau 7,73\% dari luas wilayah Kabupaten Timor Tengah Utara dan sebagian wilayah berbatasan dengan pantai dengan kisaran ketinggian 
400 mdpl. Secara demografis penduduk Kecamatan Biboki Anleu didominasi oleh laki-laki sebanyak 8.258 orang atau $50,7 \%$ sementara perempuan hanya sebanyak 8024 orang dengan persentase adalah 49,3\%. mata pencaharian masyarakat di Kecamatan Biboki Anleu terdapat beberapa jenis pekerjaan antara lain Petani/peternak, Nelayan, Pensiunan, PNS, Pegawai Swasta, TNI, POLRI dan Wiraswasta sebagian didominasi oleh Petani/peternak sebanyak 4.344 orang atau persentase $91,5 \%$, Nelayan 31 orang atau persentase $2,1 \%$, Pensiunan, 33 orang atau $0,7 \%$, PNS 181 orang atau 3,8\%, pegawai Swasta 29 orang atau $0.6 \%$, TNI dan POLRI sebanyak 51 orang atau $1,1 \%$ serta wiraswasta sebanyak 49 orang atau $1,0 \%$. Adapun jenis ternak yang ada di Kecamatan Biboki Anleu, Kabupaten Timor Tengah Utara adalah sapi, kerbau, kuda, kambing, babi, ayam buras. Kecamatan ini didominasi oleh ternak ayam sebanyak 10.977 ekor, atau $30,2 \%$ sapi sebanyak 8.888 ekor atau $24,5 \%$ babi 8.069 ekor atau $22,2 \%$, kerbau 388 ekor atau $1,1 \%$, kuda sebanyak 13 ekor atau $0.04 \%$ (BPS TTU, 2017).

\subsection{Kondisi Populasi Ternak Kerbau di Kecamatan Biboki Anleu}

Kondisi populasi ternak kerbau di Kecamatan Biboki Anleu, Secara struktural dari tahun 2014, 2015, 2016 hingga 2017 mengalami fluktuatif populasi, pada hasil penelitian empat (4) tahun berturut-turut menunjukkan bahwa populasi ternak kerbau di Biboki Anleu sangat berpotensi jika dilihat dari persentase Natural increase sebesar 19,2\% (tabel 5), hal ini didukung tinggi ratarata persentase angka kelahiran (Calving Rate) ternak kerbau sebesar 57,55 \pm 9,34 (Tabel 1.), rasio pejantan yang menunjang tingginya hal ini akan berdampak terhadap tingginya persentase Efisiensi Reproduksi (ER), serta melihat pada pendekatan analisis potensi pengembangan wilayah dengan menggunakan metode Location Quationts (LQ) nilai N menunjukkan >5 atau nilai 5,77, luas wilayah. Menurut hasil penelitian Tonbesi (2009), umumnya pertambahan alami ternak sapi di Kabupaten Timor Tengah Utara menunjukkan stabil, dengan persentase Natural Increase (NI) sebesar 21,72\% dan Efisiensi Reproduksi (ER) sebesar $83,60 \%$. Fluktuatifnya populasi ternak kerbau saat ini disebabkan oleh tingginya persentase angka mortalitas pada ternak muda sebesar 43,5\% (tabel 2), dan persentase angka penjualan pada ternak dewasa 61\% (Tabel 3.) yang tidak terukur yang dapat berpengaruh terhadap naik turunnya populasi ternak kerbau di Kecamatan Biboki Anleu (Tabel 4.).

Secara umum kondisi dinamika populasi ternak kerbau di Kecamatan Biboki Anleu sebagai berikut:

a. Angka Kelahiran ( Calving Rate)

Angka kelahiran merupakan jumlah induk yang bergudel dari populasi induk. Atau gudel yang lahir merupakan keberhasilan perkawinan jantan dan betina yang dinyatakan dalam persen $(\%)$.

Tabel 1. Angka kelahiran ternak kerbau di Kecamatan Biboki Anleu Kabupaten Timor Tengah Utara (TTU)

\begin{tabular}{|c|c|c|c|c|c|c|c|c|}
\hline \multirow{2}{*}{\multicolumn{2}{|c|}{ No Tahun }} & \multicolumn{3}{|c|}{ Jenis kelamin } & \multirow[b]{2}{*}{ Induk } & \multirow[b]{2}{*}{ Pejantan } & \multirow{2}{*}{$\begin{array}{l}\text { Rasio } \\
\text { Jantan } \\
\text { Betina }\end{array}$} & \multirow{2}{*}{$\begin{array}{c}\text { Persentase } \\
(\%)\end{array}$} \\
\hline & & Jantan & Betina & Jumlah & & & & \\
\hline & 2017 & $45 \pm 1,36$ & $45 \pm 0,98$ & $90 \pm 2,89$ & $125 \pm 2,25$ & $37 \pm 6,08$ & $1: 3$ & 70,4 \\
\hline & 2016 & $44 \pm 1,36$ & $38 \pm 1,22$ & $82 \pm 2,14$ & $144 \pm 2,72$ & $39 \pm 6,24$ & $1: 4$ & 48 \\
\hline & 2015 & $45 \pm 1,55$ & $40 \pm 1,86$ & $84 \pm 2,24$ & $161 \pm 3,43$ & $31 \pm 5,57$ & $1: 5$ & 559 \\
\hline & 2014 & $44 \pm 1,56$ & $40 \pm 1,22$ & $84 \pm 2,46$ & $175 \pm 3,87$ & $22 \pm 4,69$ & $1: 8$ & 559 \\
\hline & $44,5 \pm 1,46$ & $40,75 \pm 1,32$ & $85 \pm 2,43$ & $151,25 \pm 3,07$ & $32,25 \pm 5,65$ & $1: 5$ & 57,55 \\
\hline
\end{tabular}

Hasil penelitian pada Tabel 1. menunjukkan bahwa angka kelahiran ternak kerbau di Kecamatan Biboki Anleu cukup tinggi terutama pada tahun 2017 sebanyak $90 \pm 2,89$ ekor atau sebesar 70,4\%, 2016 sebanyak 82 $\pm 2,14$ ekor atau $56,9 \%$, tahun 2015 sebanyak $85 \pm 2,24$ ekor atau $55,9 \%$, tahun $201484 \pm 2,46$ ekor atau 48,0\%. Tingginya persentase angka kelahiran di tahun 2017 dan rendahnya angka kelahiran di tahun-tahun sebelumnya diduga disebabkan oleh beberapa faktor, salah satunya kurangnya rasio pejantan, tanpa adanya kontrol terhadap sistem penyapihan gudel namun perkawinan ternak dibiarkan pada alam, yang berdampak terhadap panjangnya masa ovulasi yang tidak dibuahi sel sperma dan mengalami kondisi estrus post partum (EPP) didukung dengan lamanya kebuntingan mencapai 330 hari (11 bulan) dengan jarak beranak mencapai 1416 bulan. Hal ini akan berdampak terhadap tingginya kondisi ternak mengalami anestrus post partum (APP) yang panjang. Menurut Samsuandi dkk., (2016), lama kebuntingan 310-330 hari, jarak antara melahirkan sampai bunting kembali 4-6 bulan, selang bergudel 14-16 bulan. Ditambahkan Westhuizen $d k k$., (2001), bahwa penyapihan pedet yang lebih awal akan mempercepat kembalinya kondisi badan induk dan kembalinya sekresi hormon yang mendukung perkembangan ovarium sehingga akan memperpendek anestrus post partus (APP). Faktor kedua adalah kondisi alam yang mana pada tahun 2014, 2015, 2016 curah hujan di lokasi penelitian tidak menentu yang menyebabkan kurang persediaan pakan, yang berdampak terhadap konsentrasi sekresi hormon yang dapat mendukung perkembangan ovarium yang siap untuk dibuahi oleh sel telur. Faktor ketiga adalah sistem manajemen yang masih bersifat tradisional baik pemeliharaan, dan pengaturan perkawinan.

\section{b. Angka Kematian Ternak Kerbau di Kecamatan Biboki Anleu.}

Data hasil penelitian pada tabel 2. menggambarkan rata-rata kematian gudel sebanyak $16,3 \pm 3,25$ ekor atau $18,8 \%$, kematian ternak muda sebanyak $19,8 \pm 1,11$ ekor atau $43,5 \%$ dan kematian ternak dewasa sebanyak 8,5 $\pm 0,73$ ekor atau $5,5 \%$. Jika melihat berdasarkan rekam empat (4) tahun terakhir kematian ternak kerbau muda cukup tinggi dibandingkan dengan gudel, diduga penyebab kematian pada ternak kerbau muda disebabkan oleh infeksi penyakit tertentu yang ditandai dengan bulu dan berdiri, pada bagian perut membesar, dan berdiri tidak tenang. Hal ini dijelaskan oleh Indranngsih \& Sani (2013) pada penelitian sapi potong, neonatal mortalitas pada ternak muda dapat diduga infeksinya penyakit tertentu, kurangnya adaptasi akan struktur mekanisme pakan sehingga berdampak pada diare, neonatal mortality dapat disebabkan oleh beberapa faktor yang saling berkaitan antara lain gangguan metabolik, diare infeksius dan noninfeksius, gangguan nutrisional, penyakit infeksius dan non-infeksius serta gangguan reproduksi pada induk. Namun pada hasil penelitian Mullik \& Jelantik (2008) pada ternak sapi hasil menunjukkan bahwa, puncak kematian pertama adalah pada bulan pertama dilahirkan dikarenakan pedet kurang asupan susu induk sehingga tidak mencukupi kebutuhan pokok hidup dan pembentukan kekebalan tubuh yang kurang baik. Puncak kematian kedua adalah pada awal musim hujan. Selain itu, terjadi karena merebaknya berbagai penyakit dan parasit yang menyerang pedet, sehingga yang akan menjadi korban adalah pedet yang kondisi tubuhnya kurang baik karena status nutrisi yang rendah. Berdasarkan hasil penelitian tingkat kematian ternak kerbau di Kecamatan Biboki Anleu tertinggi pada jenis ternak muda yang mana menempati persentase $56 \%$ dari Gudel dari struktur populasi yang ada. Hal ini diduga bahwa tingkat kematian ternak kerbau terutama Muda dan Gudel adalah rata-rata kematian terjadi pada musim panas disebabkan kurangnya asupan pakan dan kurangnya perhatian serta pemberian pakan tambahan berupa putak (Coripha gebanga), lamtoro (Leucenna leucoceplla), turi (Sesbanieae grandiflora), gamal (Gliricidia sepium) yang mana pada puncak musim panas, serta tata laksana yang mengadopsi sistem tradisional dan rata-rata tingkat pendidikan peternak yang rendah sehingga berdampak terhadap kurang pengadopsian inovasi baru yang dapat meningkatkan pengembangan ternak kerbau.

c. Angka Penjualan dan Perilaku Penjualan

Angka penjualan ternak kerbau di Kecamatan Biboki Anleu terbagi atas dua yaitu angka penjualan ternak kerbau muda dan angka penjualan ternak dewasa. Angka penjualan ternak muda adalah jumlah penjualan per tahun dibagi dengan populasi ternak kerbau per tahun. Angka penjualan dewasa adalah jumlah penjualan ternak dewasa per tahun dibagi dengan populasi ternak kerbau per tahun. Usaha pengembangan beternak kerbau yang dilakukan oleh peternak di Kecamatan Biboki Anleu, umumnya dilakukan sebagai upaya investasi yang bertujuan untuk membiayai pendidikan anak, memenuhi kebutuhan Rumah Tangga (RT), kegiatan sosial budaya (adat-istiadat), dan pemenuhan perlengkapan pertanian yang mana peran ternak kerbau telah tergantikan dengan alat pertanian.

Tabel 2. Angka Mortalitas ternak kerbau di Kecamatan Biboki Anleu Kabupaten Timor Tengah Utara (TTU)

\begin{tabular}{cccccccccc}
\hline \multirow{2}{*}{ Tahun } & \multicolumn{3}{c}{ Populasi } & \multicolumn{3}{c}{ Kematian } & \multicolumn{3}{c}{ Persentase (\%) } \\
\cline { 2 - 9 } & Gudel & Muda & Dewasa & Gudel & Muda & dewasa & Gudel & Muda & Dewasa \\
\hline 2017 & $84 \pm 2,24$ & $50 \pm 2,08$ & $140 \pm 2,62$ & $22 \pm 1,33$ & $28 \pm 1,56$ & $11 \pm 0,86$ & 25 & 56 & 8 \\
2016 & $82 \pm 2,14$ & $49 \pm 1,57$ & $160 \pm 3,23$ & $15 \pm 1,31$ & $15 \pm 0,96$ & $14 \pm 1,25$ & 18 & 29 & 9 \\
2015 & $90 \pm 2,89$ & $52 \pm 2,03$ & $163 \pm 3,66$ & $16 \pm 0,97$ & $17 \pm 0,97$ & $7 \pm 0,60$ & 18 & 33 & 4 \\
2014 & $84 \pm 2,46$ & $34 \pm 1,64$ & $184 \pm 4,57$ & $12 \pm 1,03$ & $19 \pm 0,94$ & $2 \pm 0,22$ & 14 & 56 & 1 \\
\hline Rerata & $86 \pm 2,43$ & $46 \pm 1,83$ & $162 \pm 3,52$ & $16,3 \pm 1,1619,8 \pm 1,118,5 \pm 0,73$ & 18,8 & 43,5 & 5,5 \\
\hline
\end{tabular}

Sementara usia non produktif cenderung tidak menjual ternaknya namun transaksi penjualan hanya untuk membiayai kebutuhan rumah tangga. Tinginya penjualan yang terjadi pada usia produksi yang terindikasi bahwa pada usia produksi cenderung menjual ternaknya untuk membiayai hidupnya dan pendidikan sebagai skala prioritas. Hal ini pun tergambar dari motto umum masyarakat bahwa "lebih baik kaya akan tingginya tingkat pendidikan anak ketimbang kaya akan harta benda yang akan musnah kapan saja". Motto ini menjadi paradigma baru masyarakat terhadap kepedulian tingkat pendidikan, hal ini didukung dengan hasil wawancara yang terdapat pada pernyataan kuesioner tentang jumlah tanggungan keluarga pada level perguruan tinggi dari 39 responden terdapat 156 orang dari level pendidikan yang berbeda. Hasil Tabel 6 . tentang jumlah pelajar dalam tanggungan keluarga, terdapat persaingan yang ketat antara level pendidikan tinggi, menengah, dan pendidikan dasar masingmasing, Perguruan Tinggi sebanyak 41 orang atau 26,3\%, Sekolah Menengah Atas 44 orang atau 28,2\%, tingkat Sekolah Dasar 45 orang atau 28,9\%, diasumsikan bahwa rata-rata satu peternak kerbau di Kecamatan Biboki Anleu memiliki satu orang yang menyandang pendidikan tinggi dan pendidikan menengah atas.

d. Populasi Ternak Kerbau di Kecamatan Biboki Anleu

Populasi ternak kerbau yang meliputi banyaknya jumlah gudel kerbau (gudel), kerbau muda, dan kerbau dewasa. Data hasil penelitian pada Tabel 4 menunjukkan bahwa peternak di Kecamatan Biboki Anleu rata-rata peternak berada pada kategori kurang yang ditempati 21 orang dengan persentase $53,8 \%$, kategori sedang ditempati 12 orang dengan persentase $30,8 \%$ dan banyak 4 orang dengan persentase $10,3 \%$ serta kategori sangat banyak terdapat 2 orang dengan persentase $5,1 \%$. Dari data hasil penelitian menunjukkan bahwa tingkat motivasi dan populasi ternak kerbau di Kecamatan Biboki Anleu memiliki populasi cukup banyak walau tidak diimbangi dengan pendidikan rendah Ditambahkan oleh Utami $d k k$., (2016), bahwa tinggi rendahnya pendidikan yang dimiliki oleh peternak tidak menjamin bahwa mereka akan mengembangkan usahanya, sebab tidak ada perbedaan antara jumlah kepemilikan ternak dilihat dari segi pendidikan 
Tabel 3. Angka penjualan ternak kerbau di Kecamatan Biboki Anleu Kabupaten Timor Tengah Utara (TTU).

\section{Angka penjualan dari populasi}

\begin{tabular}{ccccccccc}
\hline \multirow{2}{*}{ No } & \multirow{2}{*}{ Tahun } & \multicolumn{2}{c}{ Populasi } & \multicolumn{2}{c}{ Penjualan } & \multicolumn{3}{c}{ Persentase } \\
\cline { 2 - 8 } & & Muda & Dewasa & Muda & Dewasa & $\%$ & $\%$ & $\Sigma \%$ \\
\hline a & 2017 & $50 \pm 2,08$ & $140 \pm 2,62$ & $21 \pm 0,72$ & $39 \pm 2,32$ & 0,4 & 78 & 78 \\
b & 2016 & $49 \pm 1,57$ & $160 \pm 3,23$ & $30 \pm 1,58$ & $30 \pm 1,71$ & 0,6 & 61 & 62 \\
c & 2015 & $52 \pm 2,03$ & $163 \pm 3,66$ & $25 \pm 1,22$ & $22 \pm 1,27$ & 0,5 & 42 & 43 \\
d & 2014 & $34 \pm 1,64$ & $184 \pm 4,57$ & $24 \pm 1,14$ & $20 \pm 1,07$ & 0,7 & 59 & 60 \\
\multicolumn{2}{c}{ Rerata } & $46 \pm 1,83$ & $162 \pm 3,52$ & $25 \pm 1,17$ & $28 \pm 1,59$ & 0,6 & 60 & 61
\end{tabular}

2. Volume penjualan terhadap biaya pendidikan, kebutuhan RT, kegiatan sosial budaya, dan perlengkapan Pertanian

\begin{tabular}{lcc}
\hline \multicolumn{1}{c}{ Jenis } & Frekuensi & Persentase \\
\hline a. Pendidikan & 8 & 20,5 \\
b. perlengkapan Pertanian & 3 & 7,7 \\
c. Rumah Tangga (adat) & 7 & 17,9 \\
d. Pendidikan \& Perlengkapan Pertanian & 12 & 30,8 \\
e. Pendidikan \& Rumah Tangga (adat) & 2 & 5,1 \\
f. Rumah Tangga \& Perlengkapan Pertanian & 6 & 15,4 \\
g.pendidikan, RT\& Perlengkapan Pertanian & 1 & 2,6 \\
\hline
\end{tabular}

3. Kelompok penjualan ternak

\begin{tabular}{lcccccc}
\hline Perilaku (usia) & \multicolumn{7}{c}{ Volume Penjualan (Ekor) } \\
\cline { 2 - 7 } & Tidak menjual & $1-3$ & $4-6$ & $7-9$ & $>10$ & Total \\
\hline $\begin{array}{l}\text { Usia Produktif (15-64 tahun) } \\
\begin{array}{l}\text { Usia Non Produktif (65-90 } \\
\text { tahun) }\end{array}\end{array}$ & 6 & 8 & 7 & 5 & 5 & 31 \\
\hline Jumlah & 2 & 3 & 2 & 1 & 0 & 8 \\
\hline
\end{tabular}

Data penelitian Tabel 4. pada bagian kedua terdapat angka fluktuatif populasi ternak kerbau dari tahun 2017 sebanyak $257 \pm 6,12$ ekor dengan persentase sebesar $22,9 \%$, tahun 2016 sebanyak $277 \pm 5,30$ ekor dengan persentase $24,7 \%$, tahun 2015 sebanyak $304 \pm 6,99$ ekor dengan persentase sebanyak $27,1 \%$, tahun 2014 , sebanyak $285 \pm 7,15$ ekor dengan persentase sebanyak $25,4 \%$, dari total populasi sebanyak 1.123 ekor selama empat tahun terakhir. Peningkatan populasi pada tahun 2015 dapat diduga bahwa pada tahun tersebut terdapat penekanan angka kematian dan angka penjual yang begitu sedikit dari tahun lainnya hal ini terlihat pada Tabel 2. Angka kematian dan Tabel 3. Angka penjualan ternak kerbau di Kecamatan Biboki Anleu.

Tabel 4. Populasi ternak kerbau di Kecamatan Biboki Anleu Kabupaten Timor Tengah Utara (TTU)

\begin{tabular}{|c|c|c|}
\hline 1. Kategori populasi & Frekuensi (orang) & Persentase \\
\hline a. $1-5$ ekor (kurang) & 21 & 53,8 \\
\hline b. 6-10 ekor (sedang) & 12 & 30.8 \\
\hline c. $11-15$ ekor (banyak) & 4 & 10,3 \\
\hline d. >16 ekor (sangat banyak) & 2 & 5,1 \\
\hline
\end{tabular}

\section{Populasi ternak}

\begin{tabular}{|c|c|c|c|c|c|c|c|c|}
\hline \multirow{2}{*}{ Tahun } & \multicolumn{2}{|c|}{ Gudel } & \multicolumn{2}{|c|}{ Muda } & \multicolumn{2}{|c|}{ Dewasa } & \multirow{2}{*}{$\Sigma$} & \multirow{2}{*}{$\%$} \\
\hline & Jantan & Betina & Jantan & Betina & Jantan & Betina & & \\
\hline 2017 & $33 \pm 1,55$ & $34 \pm 0,95$ & $22 \pm 1,33$ & $28 \pm 1,37$ & $15 \pm 0,94$ & $125 \pm 2.25$ & $7 \pm 6,12$ & 22,9 \\
\hline 2016 & $41 \pm 1,30$ & $27 \pm 0,92$ & $23 \pm 0,79$ & $26 \pm 1$ & $16 \pm 0,91$ & $144 \pm 2$ & $7 \pm 5,30$ & 24,7 \\
\hline 2015 & $48 \pm 1,58$ & $40 \pm 1,63$ & $28 \pm 1,49$ & $24 \pm 1,07$ & $3 \pm 0,35$ & $161 \pm 3,43$ & $4 \pm 6,99$ & 27,1 \\
\hline 2014 & $37 \pm 1,52$ & $30 \pm 0,96$ & $13 \pm 1,03$ & $21 \pm 1,12$ & $9 \pm 0,90$ & $175 \pm 3,87$ & $5 \pm 7,15$ & 25,4 \\
\hline Rerata & $40 \pm 1,49$ & $33 \pm 1,12$ & $22 \pm 1,16$ & $25 \pm 1,18$ & $11 \pm 0,78$ & $151 \pm 3,07$ & $1 \pm 6,39$ & 25,03 \\
\hline
\end{tabular}

\section{e. Pertambahan Alami (Natural Increase)}

Natural Increase adalah selisih antara angka kematian dan angka kelahiran yang dinyatakan dalam persen. Nilai natural increase diperlukan agar pertambahan populasi ternak secara alami dalam satu periode dari suatu wilayah dapat diketahui.

Tabel 5. Pertambahan alami/ Natural Increase (NI) ternak kerbau Kecamatan Biboki Anleu Kabupaten Timor Tengah Utara (TTU)

\begin{tabular}{lcccc}
\hline Tahun & Kematian & Kelahiran & Induk & Persentase (\%) \\
\hline 2017 & $22 \pm 1,33$ & $84 \pm 2,24$ & $125 \pm 2,25$ & 26,2 \\
2016 & $15 \pm 1,31$ & $82 \pm 2,14$ & $144 \pm 2,72$ & 18,3 \\
2015 & $16 \pm 0,97$ & $90 \pm 2,89$ & $161 \pm 3,43$ & 17,8 \\
2014 & $12 \pm 1,03$ & $84 \pm 2,46$ & $175 \pm 3,87$ & 14,3 \\
\hline Rerata & $16,3 \pm 1,16$ & $85 \pm 2,46$ & $125 \pm 2,25$ & 19,2 \\
\hline
\end{tabular}

Data Tabel 5. persentase Natural Increase (NI) di Kecamatan Biboki Anleu cukup tinggi dari tahun-tahun sebelumnya, melihat tingginya persentase NI tinggi maka Kecamatan Biboki Anleu dapat digolongkan sebagai wilayah yang sangat berpotensi untuk beternak kerbau. Hal ini didukung dengan karakteristik peternak, ketersediaan pakan, luas lahan penggembalaan dan kepadatan penduduk di Kecamatan Biboki Anleu yang tidak sebanding dengan luas wilayah. Potensi pengembangan usaha beternak kerbau melihat pada pendekatan analisis potensi pengembangan wilayah melalui metode Lokation Quationts (LQ) menurut Budiharsono (2001) hasil pembagian antara jumlah populasi ternak desa/kecamatan dibagi jumlah kepala keluarga dan jumlah populasi ternak tingkat kabupaten dibagi jumlah kepala keluarga tingkat kabupaten jika hasil lebih besar dari 1 maka wilayah tersebut sangat berpotens untuk pengembangan. Menurut BPS TTU (2017), jumlah kepala keluarga yang berada di Kecamatan Biboki Anleu sebanyak 3.914 Kepala Keluarga (KK) dengan populasi ternak kerbau saat ini sebanyak 257 ekor, sementara jumlah KK di Kabupaten Timor Tengah Utara sebanyak 59. 886 KK dengan populasi ternak kerbau sebanyak 681 ekor. Hasil perhitungan matematisnya adalah 5,77 atau $\mathrm{N}$ $>1$. Dengan demikian Kecamatan Biboki Anleu sangat berpotensi untuk usaha pengembangan ternak kerbau baik dilihat dari analisis Natural Increasenya maupun melalui pendekatan analisis potensi pengembangan wilayahnya. Ditambahkan dengan luas wilayah Kecamatan Biboki Anleu adalah 206,40 km² dengan jumlah penduduk 16.282 orang . Jika dihitung secara matematis maka satu orang penduduk Kecamatan Biboki Anleu berhak menempati $79 \mathrm{~km}^{2}$. Artinya luasan yang ada sangat berpeluang untuk beternak kerbau, luas lahan yang ada akan meminimalisir tingkat kompetisi antara peternak, ternak, dan ternak sendiri untuk mencari pakan alami. Menurut Sodiq \& Abidin (2008), faktor penghambat dalam usaha peternakan yaitu berkurangnya minat para petan atau peternak untuk memelihara ternak, karena lahan pertanian yang dimiliki semakin menyempit akibat banyak yang digunakan sebagai lahan pemukiman, sehingga mereka sulit mencari padang penggembalaan atau bahan pakan untuk ternak yang dipeliharanya. Pada penelitian sapi pedet oleh Basyir (2009), bahwa faktor yang dapat menyebabkan tingginya nilai natural increase yaitu (1) tingginya persentase betina dewasa, (2) tingginya angka kelahiran, dan (3) rendahnya angka kematian. Berdasarkan hasil penelitian maka persentase Natural Increase cukup tinggi baik kerbau maupun Sapi. Seperti penelitian sebelumnya yang dilakukan di daerah yang sama di Kabupaten Timor Tengah Utara (TTU), Provinsi Nusa Tenggara Timur, NTT oleh Tonbesi $d k k$., (2009), umumnya Natural Increase sapi menunjukkan stabil, Natural Increase 21,72\%, menunjukkan Efisiensi Reproduksi (ER) 83,60\%.

\subsection{Faktor-Faktor yang Mempengaruhi Populasi dan Perkembangan Ternak Kerbau di Kecamatan Biboki Anleu}

Peningkatan populasi ternak sebagai jawaban atas program pemerintah dalam menyediakan kebutuhan pangan atas tingginya permintaan akan kebutuhan protein hewani yang dipengaruhi tingkat komsumsi masyarakat akan daging pada tahun 2016 sebesar 2,61 kg/kapita/tahun yang berkorelasi dengan naiknya pendapatan masyarakat Indonesia, hidup pun berubah maka konsumsi daging semakin banyak pada tahun 2016 adalah 750.000 ton. (Ditjenpkh Pertanian, 2017). Adapun faktor-faktor yang mempengaruhi tingkat populasi dan perkembangan ternak kerbau antara lain, karakteristik peternak dan potensi lingkungan yang mencakup kondisi lingkungan dan ketersediaan pakan yang dapat menyuplai pakan dalam satu periode, serta keadaan sosial budaya yang merupakan hulu dari peningkatan populasi ternak itu sendiri. Hasil penelitian menunjukkan bahwa faktor-faktor yang mempengaruhi tingkat populasi ternak dan perkembangannya di Kecamatan Biboki Anleu, antara lain faktor karakteristik peternak yang meliputi tingkat usia, tingkat pendidikan, pekerjaan, pengalaman, dan jumlah tanggungan peternak yang sangat berkorelasi peningkatan populasi dan perkembangan ternak kerbau.

\subsection{Karakteristik Peternak di Kecamatan Biboki Anleu}

Karakteristik peternak merupakan salah satu ujung tombak dari tinggi rendahnya populasi ternak kerbau baik penerimaan terhadap teknologi dan inovasi yang berdampak pada meningkatkan dan pengembangan usaha beternak, manajemen perkawinan, dan pemeliharaan merupakan satu kesatuan dari kompetensi yang berdampak pada perilaku peternak dalam mempertahankan populasi ternak kerbau. Umur peternak, jenis kelamin, pengalaman, jumlah tanggungan keluarga menjadi satu kesatuan yang tidak dapat dipisahkan dari pola petani/peternak sebagai variabel yang dapat menentukan upaya dan metode pemeliharaan dan perkembangan ternak kerbau.

Beragamnya karakteristik peternak kerbau di Kecamatan Biboki Anleu yang sangat berpengaruh terhadap tinggi rendahnya skala usaha pengembangan ternak kerbau, baik pengadopsian teknologi maupun inovasi yang dapat memicu pengembangan usaha pengembangan itu sendiri. Menurut Fauziyah $d k k$. , (2015), kompetensi merupakan bagian yang paling melekat di dalam kepribadian seseorang dan dapat memprediksi perilaku dalam berbagai macam situasi dan tugas. Berkaitan dengan hal ini, terdapat lima (5) komponen kompetensi, yaitu motif, sifat, konsep diri, pengetahuan, dan keterampilan.

a. Tingkatan usia

Usia merupakan salah satu hal yang mempengaruhi perilaku dan kinerja dalam suatu kegiatan usaha yang dilakukan dimana produktivitas kerja akan meningkat bila masih dalam kondisi umur yang produktif dan semakin menurun seiring bertambahnya umur seseorang, peternak di Kecamatan Biboki Anleu dapat di kategorikan dalam dua (2) kelompok besar berdasarkan pengelompokan kekuatan fisik dan produktivitasnya yaitu : 1. Kelompok usia produktif. 2 kelompok usia Non produktif. Menurut Akmal (2016), faktor usia akan sangat berpengaruh pada pekerjaan yang sangat mengandalkan kekuatan dan kemampuan fisik tenaga kerja. Usia akan sangat mempengaruhi produktivitas kerja karena lebih dominan mengandalkan kekuatan fisik. Semakin bertambah umur peternak mengakibatkan produktivitas usaha ternak semakin menurun (Akmal, 2016).

Hasil Pada Tabel 6. menunjukkan bahwa peternak yang berada di Kecamatan Biboki Anleu didominasi oleh kelompok usia produktif, yakni sebanyak 31 orang dengan persentase sebesar 79,5\% dari 39 orang responden yang memiliki ternak saat ini, dibanding dengan usia non produktif sebanyak 
$20,5 \%$ atau sebanyak 8 orang. Data ini juga menggambarkan bahwa secara kuantitatif, usia semakin bertambah maka motivasi seseorang untuk beternak semakin tinggi sebagai salah satu investasinya, baik untuk masa tua maupun untuk membiayai pendidikan serta pengadaan pelengkapan alat pertanian.

Hasil penelitian menunjukkan bahwa umur peternak tidak berpengaruh terhadap populasi ternak kerbau. Hal ini sesuai pendapat Makatita (2013), yang mengatakan bahwa umur peternak tidak berpengaruh dengan skala usaha karena peternak yang berusia produktif lebih memperhatikan usaha taninya dibanding usaha peternakan.

\section{b. Tingkat pendidikan}

Tingkat pendidikan merupakan salah satu faktor penentuan usaha pengembangan beternak kerbau. Hasil penelitian di Kecamatan Biboki Anleu didapatkan bahwa sebagian peternak yang adalah hanya berpendidikan Sekolah Rakyat (SR) atau Sekolah Dasar (SD)

Tabel 6. Klasifikasi peternak kerbau di Kecamatan Biboki Anleu Kabupaten Timor Tengah Utara (TTU)

\begin{tabular}{|c|c|c|c|c|}
\hline 1. & Usia & Kategori & Frekuensi & Persentase \\
\hline & a. 15-64 tahun & Produktif & 31 & 79,5 \\
\hline & b. 64-90 tahun & Tidak Produktif & 8 & 20,5 \\
\hline 2. & Pekerjaan & Petani & 39 & 100 \\
\hline \multirow[t]{6}{*}{3.} & Pendidikan & & & \\
\hline & a. Non Pendidikan & & 12 & 30,8 \\
\hline & b. $\quad \mathrm{SD} / \mathrm{SR}$ & & 22 & 56,4 \\
\hline & c. SLTP & & 2 & 5,1 \\
\hline & d. SLTA & & 2 & 5,1 \\
\hline & e. Sarjana & & 1 & 2,6 \\
\hline \multirow[t]{6}{*}{4.} & Pengalaman & & & \\
\hline & a. 1-5 Tahun & Sangat Kurang & 3 & 7,7 \\
\hline & b. 6-10 Tahun & Kurang & 5 & 12,8 \\
\hline & c. 11-15 tahun & Cukup & 1 & 2,6 \\
\hline & d. 16-20tahun & Berpengaman & 9 & 23,1 \\
\hline & e. $>21$ tahun & sangat berpengalaman & 21 & 53,8 \\
\hline \multirow[t]{4}{*}{5.} & Jumlah tanggungan & & & \\
\hline & a. $2-5$ Orang & Kurang & 16 & 28,6 \\
\hline & b. 6-9 Orang & Cukup & 21 & 37,5 \\
\hline & c. $>10$ Orang & Besar & 2 & 3,6 \\
\hline \multirow[t]{5}{*}{6.} & Jumlah pelajar dalam & inggungan keluarga & & \\
\hline & a. Sekolah Dasar (S & & 45 & 28.9 \\
\hline & b. Sekolah Meneng & Pertama (SMP) & 26 & 16,7 \\
\hline & c. Sekolah Meneng & Atas (SMA) & 44 & 28,2 \\
\hline & d. Perguruan Tingg & & 41 & 26,3 \\
\hline \multirow[t]{3}{*}{7.} & Tanggung jawab pem & iharaan & & \\
\hline & a. Anggota keluarg & & 35 & 89,7 \\
\hline & b. Luar anggota kel & arga & 4 & 10,3 \\
\hline
\end{tabular}

Hasil penelitian Tabel 6. menggambarkan bahwa peternak yang berada di Kecamatan Biboki Anleu sebagian besar mengenyam pendidikan terakhir adalah Sekolah Rakyat (SR)/Sekolah Dasar (SD) sebanyak 22 orang dengan persentase $56,4 \%$ dan diikuti yang tidak bersekolah sebanyak 12 orang dengan persentase $30,8 \%$, Sekolah Menengah Pertama (SMP) sebanyak 2 orang dengan persentase 5,1\%, Sekolah Menengah Atas (SMA) 2 orang dengan persentase sebanyak $5,1 \%$ dan pendidikan tinggi sebanyak 1 orang atau 2,6\%. Rendahnya pendidikan peternak yang ada sangat berdampak pada peningkatan pengembangan dan peningkatan populasi ternak kerbau karena kurangnya pemahaman dan penyerapan teknologi dan inovasi terkini yang dapat menyumbangkan pola pemahaman peternak. Menurut Utami (2015), tinggi rendahnya pendidikan yang dimiliki oleh peternak tidak menjamin bahwa mereka akan mengembangkan usahanya, sebab tidak ada perbedaan antara jumlah kepemilikan ternak dilihat dari tingkat pendidikan. Namun usaha pengembangan ternak kerbau ini tidak akan bertahan jika tanpa adanya upaya renewable terhadap pelestarian plasma nutfah ternak kerbau seperti yang dikatakan Priyanti \& Saptati (2007), pengembangan ternak kerbau dapat digunakan sebagai pemicu pengembangan kegiatan budidaya untuk menghasilkan bakalan (cow of operation) yang mana sebagai upaya pelestarian plasma nutfah ternak kerbau, peluang ini akan semakin bertambah dengan besarnya potensi Sumber Daya Alam (SDA) dan Sumber Daya Manusia (SDM). c. Pengalaman dan sumber bibit beternak ternak kerbau

Pengalaman berternak adalah lama waktu yang telah dilalui oleh peternak dalam menjalankan suatu usaha. Semakin banyak pengalaman yang dimiliki oleh peternak maka akan bijak dalam mengambil keputusan. Dan merupakan salah satu indikator seorang peternak untuk bergelut dalam beternak itu sendiri.

Data Tabel 6. menggambarkan bahwa peternak kerbau di Kecamatan Biboki Anleu rata-rata memiliki pengalaman beternak yang lama hal ini berdasarkan hasil penelitian umumnya peternak memiliki pengalaman beternak di atas 21 tahun dengan persentase 53,8\% atau sebanyak 21 orang dari 39 orang peternak, yang berpengalaman 16-20 tahun sebanyak 9 orang atau dengan persentase $23,1 \%$ yang dapat dikategorikan sebagai yang berpengalaman. Kategori berpengalaman cukup sebanyak 1 orang atau 2,6\%, berstatus kurang berpengalaman sebanyak 5 orang atau $12,8 \%$, serta sangat kurang berpengalaman sebanyak 3 orang atau $7,7 \%$. Berdasarkan data hasil penelitian dengan pengelompokan data pada sumber awal bibit dan pengalaman beternak kerbau, maka dapat dikategorikan bahwa peternak umumnya memiliki motivasi yang tinggi yaitu dengan berusaha sendiri baik itu membeli maupun dibarter dengan ternak yang lain. Menurut Iskandar dan Arfa'i (2007), umur dan pengalaman beternak akan mempengaruhi kemampuan peternak dalam menjalankan usaha, peternak yang mempunyai pengalaman yang lebih banyak akan selalu hati-hati dalam bertindak dengan adanya pengalaman buruk dimasa lalu.

Menurut Utami (2015), umumnya pengalaman beternak diperoleh dari orang tuanya secara turun temurun. Pengalaman beternak yang cukup lama memberikan indikasi bahwa pengetahuan dan keterampilan peternak terhadap manajemen pemeliharaan ternak mempunyai kemampuan yang lebih baik. Hal ini sesuai dengan hasil penelitian berdasarkan sebaran pertanyaan yang diguna peneliti tentang Sumber awal bibit beternak kerbau menunjukkan bahwa sebagiannya status kepemilikan ternak kerbau adalah warisan Orang tuanya.

d. Jumlah tanggungan keluarga dan tenaga kerja.

Jumlah tanggungan keluarga merupakan jumlah anggota keluarga yang menjadi tanggungan responden untuk dinafkahi dan salah satu faktor yang dapat mempengaruhi peningkatan populasi ternak kerbau yang berkorelasi dengan .penggunaan tenaga kerja keluarga yang bertanggung jawab terhadap perkembangan ternak kerbau.

Berdasarkan hasil penelitian peternak yang ada di Kecamatan Biboki Anleu rata-rata didominasi oleh jumlah tanggungan dengan kategori cukup (6-9 orang) sebanyak $37,5 \%$ serta jumlah kategori kurang sebesar $28,6 \%$, serta jumlah tanggungan lebih besar dari 10 orang sebanyak 2 orang peternak/responden. Hasil pada Tabel 1. menunjukkan bahwa umumnya peternak kerbau di Kecamatan Biboki Anleu memiliki beban tanggungan anggota keluarga yang cukup besar, berdasarkan hasil wawancara dalam pernyataan kuesioner terdapat 21 orang peternak dari 39 orang peternak yang memiliki beban tanggungan sebanyak $37,5 \%$. Tingginya persentase jumlah tanggungan keluarga peternak sangat berkorelasi tenaga kerja dan tanggung jawab pemeliharaan ternak kerbau itu sendiri. Hal ini sesuai dengan pendapat Murwanto (2008) yang menyatakan bahwa tenaga kerja pada usaha peternakan pada umumnya masih menggunakan tenaga kerja keluarga dan banyak digunakan untuk kegiatan pengembangan.

Data pada Tabel 6. menggambarkan tingginya partisipasi anggota terhadap pemeliharaan ternak kerbau masih cukup tinggi sehingga dapat mengurangi biaya tenaga kerja luar anggota keluarga namun konsentrasi biaya sangat berpengaruh terhadap mahalnya biaya pendidikan tinggi yang merupakan bagian dari tanggungan peternak di kecamatan Biboki Anleu. Hal ini di gambarkan pada Tabel 2. bahwa motivasi berternak selain untuk meningkatkan status sosial di tengah masyarakat namun orientasi akan pendidikan gudel dan pengadaan perlengkapan pertanian sebagai salah satu indikator keberhasilan orang tersebut. Klasifikasi responden peternak berdasarkan jumlah tanggungan pendidikan tinggi yang ada pada daftar pertanyaan tentang jumlah jenis tanggungan keluarga terhadap pendidikan yang dapat menguras populasi hal in jika dilihat dari rekam populasi empat (4) tahun terakhir yang semakin menurun. Selain tingginya biaya pendidikan, terdapat juga jenis tanggung jawab pemeliharaan ternak kerbau luar anggota keluarga sebanyak 4 orang atau dengan persentase sebanyak $10 \%$, yang dibiayai atau diupahkan dari pemilik ternak dengan sistem bagi hasil, yang mana setiap kali ternak kerbau bergudel akan diberikan satu ekor dari populasi gudel yang ada. Artinya setiap kali induk kerbau yang bergudel tenaga kerja luar anggota keluarga berhak mendapatkan satu ekor sebagai upah selama pemeliharaan walau terkesan kapitalis namun tradisi ini telah mendarah daging. Umumnya kepemilikan ternak kerbau selain warisan, dan usaha membeli terdapat pula usaha upahan dari beternak kerbau. Hasil penelitian yang didapat sebaran pertanyaan tentang sumber awal kepemilikan ternak menunjukkan bahwa status kemilikan ternak kerbau adalah upahan hasil pemeliharaan pada orang lain yang memiliki ternak kategori banyak yang dijalani oleh masyarakat saat ini.

\subsection{Tata Laksana dan Motivasi Pemeliharaan Ternak Kerbau di Kecamatan Biboki Anleu}

Usaha pemeliharaan ternak kerbau sangat bergantung terhadap karakteristik peternak, baik umur, perilaku peternak, pengalaman, pendidikan, jenis kelamin dan jumlah tanggungan serta tanggung jawab pemeliharaan. Dinamika karakteristik peternak sangat berpengaruh terhadap usaha pemeliharaan baik motivasi yang berdampak terhadap pengembangan ternak kerbau.

Usaha pemeliharaan ternak kerbau di Kecamatan Biboki Anleu merupakan usaha sambilan dan pemeliharaannya juga masih dilakukan secara tradisional. Umumnya masyarakat memelihara kerbau pada lahan kosong yang tersedia. Pada pemeliharaan ini tidak dilakukan pemberian pakan konsentrat melainkan hanya memberikan pakan tambahan pada musim paceklik dimana ketersediaan hijauan di alam berkurang atau tidak ada, cara alternatifnya adalah pemberian pakan tambahan berupa putak (Corypha gebanga), lamtoro (Leucaena leucocephalla), turi (Sesbaniae grandiflora) dan gamal (Gliricidia sepium). Rendahnya pengadopsian akan teknologi dan inovasi pengembangan yang dipengaruhi oleh tingkat pemahaman dan pengetahuan yang rendah jika dilihat dari aspek pendidikan yang diperoleh oleh peternak dalam pemeliharaan kerbau hanya bersifat kebiasaan (turun-temurun) sangat berdampak terhadap pola pemeliharaan dan manajemen kesehatan, serta manajemen tatalaksana pemeliharaan yang dilakukan tidak setiap hari dan sebagian hak kepemilikan ternak kerbau merupakan hasil warisan dari orang tua dan tidak didukung dengan penyuluhan dari petugas peternakan. 
Pada penelitian (Nulik \& Kana Hau, 2014), pakan lokal di NTT terdiri dari rumput alam (dominan), daun leguminosa dan non-leguminosa serta beberapa sumber karbohidrat seperti putak dan ubi kayu sebagai pakan alternatif untuk meningkatkan kualitas daging sapi. Pola pemeliharaan peternakan kerbau yang ada di Kecamatan Biboki Anleu belum tersentuh oleh kemajuan teknologi jika melihat pada tingkat pendidikan yang rendah dan tingkat pengalaman yang rendah akan pengadopsian teknologi dan inovasi baru. Begitu pula dengan sistem penjualan tanpa adanya perencanaan sehingga dapat mengadakan bakalan pengganti, namun penjualan dapat dilakukan pada waktu-waktu tertentu, saat tahun ajaran baru, pembelian perlengkapan pertanian yang mana peran pemeliharaan beternak kerbau dapat membantu peternak untuk membajak persawahan digantikan dengan traktor saat ini, dan untuk kebutuhan sosial budaya (Rumah Adat). Melihat pada sistem yang diterapkan adalah sistem turun temurun dan usia peternak yang didominasi oleh usia produktif sedang serta tingkat pendidikan yang lemah, maka akan berdampak pada pola pemeliharaan kerbau dan lemahnya penerimaan teknik-teknik modern serta informasi yang dapat bermanfaat untuk diterapkan. Ternak kerbau pada umumnya dimiliki oleh petani dalam skala kecil dan merupakan salah satu penentuan tingkat status sosial, yang hanya dimiliki oleh orang-orang tertentu, hal ini terbukti dari 3.914 Kepala Keluarga (KK) namun yang memiliki ternak kerbau hanya sebanyak 39 Kepala Keluarga.

Tabel 7. Klasifikasi peternak berdasarkan motivasi dan skala usaha beternak kerbau di Kecamatan Biboki Anleu Kabupaten Timor Tengah Utara (TTU)

\begin{tabular}{clcc}
\hline 1 & Motivasi beternak & Frekuensi & Persentase \\
\hline a & Pendidikan & 15 & 38,4 \\
b & Perlengkapan pertanian & 12 & 30,8 \\
c & Rumah tangga & 12 & 30,8 \\
\hline 2 & Pemberian jenis pakan tambahan & & \\
\hline a & Putak, Gamal, dan Lamtoro & 27 & 67,5 \\
b & Putak dan Lamtoro & 2 & 5,0 \\
c & Putak dan gamal & 3 & 7,5 \\
d & Putak & 6 & 15,0 \\
e & tidak ada pemberian & 1 & 2,5 \\
\hline 3 & Penyuluhan & Frekuensi & Persentase \\
\hline a & Ada & 37 & 5,1 \\
b & Tidak ada & Frekuensi & Persentase \\
\hline 4 & Jumlah Kepemilikan Ternak & 21 & 50,8 \\
\hline a & 1-5 ekor & 12 & 30,8 \\
b & 6-10 ekor & 4 & 10,3 \\
c & 11-15 ekor & 2 & 5,1 \\
d & $>16$ ekor & & \\
\hline
\end{tabular}

\section{Simpulan}

Kecamatan Biboki Anleu merupakan salah satu kecamatan yang sanga berpotensi untuk pemeliharaan ternak kerbau. Hal ini didukung dengan tingginya persentase angka Natural Increase (NI), Calving Rate (CR), rasio pejantan, dan potensi pengembangan wilayah dengan metode Location Quationts(LQ). Dinamika Populasi ternak kerbau dari tahun 2014, 2015, 2016, 2017 terdapat fluktuatif. Hal ini dipengaruhi oleh tiga (3) faktor besar, antara lain; karakteristik peternak, kondisi lingkungan, dan sistem manajemen yang memiliki korelasi tinggi rendahnya populasi ternak kerbau.

\section{Pustaka}

Akmal Y. 201 6. Analisis Faktor-Faktor Yang Mempengaruhi Produktivitas Tenaga Kerja Industri Kecil Kerupuk Sanjai Di Kota Bukit tinggi. Institut Pertanian Bogor. Bogor

Basyir A. 2009. Meningkatkan Efisiensi Reproduksi Melalui Kelahiran Pedet Kembar. Diakses 28 april 2018

Budihasono S. 2001. Teknik analisis Pembangunan wilayah pesisir dan lautan. Jakarta : Pradn ya Paramita. diakses 17 Mei 2018

BPS Provinsi NTT. Rilis Hasil PSPK 2011. Kementerian Pertanian - Badan Pusat Statistik

BPS Kabupaten TTU. 2017. Populasi Ternak menurut Jenis Ternak Di Kabupaten TTU, 2013 - 2016. Hal. 219- 220.

Dania I.B., Hidjaz, T., Andriani, R., Asih, M.S. 2013 Kapasitas Suplai Kerbau Bibit dan Potong di Pulau Sumbawa. Laporan penelitian. Fakultas Peternakan Universitas Mataram. Mataram.

Deptan 2008. Road Map Perbibitan Ternak. Direktorat Perbibitan, Direktorat Jenderal Peternakan, Jakarta.

DITJENPKH Pertanian 2017. Livestock and Animal Health Statistics 2017 Direktorat Jenderal Peternakan Dan Kesehatan Hewan Kementerian Pertanian RI. Jakarta.

Fauziyah D., R Nurmalina, \& Burhanuddin. 2015. Pengaruh Karakteristik Peternak Melalui Kompetensi Peternak Terhadap Kinerja Usaha Ternak Sapi Potong Di Kabupaten Bandung. Staf Pengajar Departemen Agribisnis, Fakultas Ekonomi dan Manajemen, Institut Pertanian Bogor. Jurnal Agribisnis Indonesia. 3(2): 83-96

Hasinah H. \& E. Handiwirawan. 2006. Keragaman genetik ternak kerbau di Indonesia. Prosiding lokakarya nasional usaha ternak kerbau mendukung program kecukupan daging sapi. Pusat Penelitian dan Pengembangan Peternakan, Bogor.

Hellyward J, F. Rahim \& Arlinda. 2000. Pemeliharaan Ternak Kerbau Lumpur, Ditinjau dari Aspek Teknis Pemeliharaan di Sumatera Barat. Jurnal Peternakan 6 (1): 77-85.

Indraningsih, \& Y. Sani. 2013. Identifikasi Penyebab Kematian Sapi Potong Dalam Program PSDS-K Di Jawa Tengah. Seminar Nasional Teknologi Peternakan dan Veterine. Balai Besar Penelitian Veteriner, J1. RE Martadinata No. 30, Bogor 16114

Makatita J. 2013. Hubungan Antara Karakteristik Peternak Dengan Skala Usaha Pada Usaha Peternakan Kambing Di Kecamatan Leihitu Kabupaten Maluku Tengah. Agrinimal, 3(2) p:78-83

Mullik M \& Jelantik. I. G. N., 2009. Strategi Peningkatan Produktivitas Sapi Bali Pada Sistem Pemeliharaan Ekstensif Di Daerah Lahan Kering: Pengalaman Nusa Tenggara Timur . Fapet Universitas Nusa Cendana

Murwanto A.G.2008. Karakteristik Peternak dan tingkat Masukan Teknologi peternakan sapi potong di lembah Prafi Kabupaetn Manokwari. Jurnal Ilmu Peternakan, 3(1) p: 8-15

Nulik J \& D. Kana Hau. 2014. The potency of using and developing and introduce herbaceous legume forages in East Nusa Tenggara, Indonesia. In: Proceedings of the $16^{\text {th }}$ AAP Congres. Yogyakarta, 10-14 November 2014. Yogyakarta (Indonesia).

Priyanti A \& R.A. Saptati. 2007. Analisis Ekonomi dan Tata Niaga Usaha ternak Kerbau Lokakarya Nasional Usaha Ternak Kerbau Mendukung Program Kecukupan Daging Sapi. Skripsi. Pusat Penelitian dan Pengembangan PeternakanJln. Raya Pajajaran. Bogor.

Samsuandi R., E.M.Sari \& M.A.N Abdullah. 2016. Performans Reproduksi Kerbau Lumpur (bubalus bubalis) Betina di Kecamatan Simeulue Barat Kabupaten Simeulue. Program Studi Peternakan, Fakultas Pertanian, Universitas Syiah Kuala.

Sodiq \& Abidin. 2008. Meningkatkan Produksi Susu Kambing Pergudelan Ettawa.Agromedia Pustaka, Jakarta SelatanSugiyono. 2000. Statistik untuk penelitian (cetakan ke 3). Bandung : Alfabeta.

Sugiyono 2007. Metode Penelitian kualitas kuantitas dan R\&D. Bandung : CV. Alfa Beta

Tonbesi T.T., N Ngadiyono, \& Sumadi. 2009. The Potency Estimation And Performance Of Bali Cattle In Timor Tengah Utara Regency, East Nusa Tenggara Province. Fakultas Peternakan, Universitas Gadjah Mada, Jl. Fauna No.3, Bulaksumur, Yogyakarta, 55281. Buletin Peternakan Vol. 33(1): 30-39, Februari 2009. ISSN 0126-4400

Utami L.S. 2015. Hubungan Karakteristik Peternak Dengan Skala Usaha Ternak Kerbau Di Desa Sumbang Kecamatan Curio Kabupaten Enrekang. Fakultas Peternakan Universitas Hasanuddin. Makassar

Westhuizen R.R., S.J. Schoeman, G.F. Jordan and J.B. Van Wyk. 2001. Genetic Parameters for Reaproductive Traits in A Beef Catlle Herd Estimated UsingMultitraits Analysis. http://www.sasas.co.za/sajas.html (27 April 2018) 